\title{
Seasonal variation in the biochemical composition of red seaweed (Catenella repens) from Gangetic delta, northeast coast of India
}

\author{
Kakoli Banerjee ${ }^{1}$, Rajrupa Ghosh ${ }^{1, *}$, Sumit Homechaudhuri ${ }^{2}$ and Abhijit Mitra ${ }^{1}$ \\ ${ }^{1}$ Department of Marine Science, University of Calcutta, 35 Ballygunge Circular Road, Kolkata 700 019, India. \\ ${ }^{2}$ Department of Zoology, University of Calcutta, 35 Ballygunge Circular Road, Kolkata 700 019, India. \\ *e-mail: rajrupa14@gmail.com
}

The biochemical composition of red seaweeds, Catenella repens was investigated in this present study along with subsequent analysis of relevant physico-chemical variables. In this study, the relationship between the nutritive components of this species and the ambient environmental parameters was established. Protein content varied from $2.78 \pm 0.30 \%$ of dry weight (stn.3) to $16.03 \pm 0.96 \%$ of dry weight (stn.1) with highest values during monsoon. The protein levels were positively correlated with dissolved nitrate content and negatively correlated with water temperature (except stn.3) and salinity. Carbohydrate content of this species varied significantly $(p<0.05)$ during pre-monsoon between stations and the values showed positive relationship with salinity and surface water temperature. In contrast to carbohydrate, lipid concentration was lowest in values and varied very slightly between seasons and stations. Astaxanthin content of the seaweed species was greater in pre-monsoon than monsoon and post-monsoon in all the selected stations. Compared with the three seasons, samples of red seaweed collected in pre-monsoon has high carbohydrate-astaxanthin in contrast to protein-lipid which showed high values during monsoon. Statistical analysis computed among the environmental and biochemical parameters suggests the potential role played by the abiotic parameters on biosynthetic pathways of seaweed. This paper also highlights the influence of the nutritional quality of water that can be used for mass cultivation of Catenella repens.

\section{Introduction}

About eight million tonnes wet seaweeds are harvested annually worldwide and stranded seaweed on the beach constitute a considerable part of it (McHugh 2003). Currently, human consumption of green algae (5\%), brown algae $(66.5 \%)$ and red algae $(33 \%)$ is high in Asia, mainly Japan, China and Korea (Dawes 1998). However, demand for seaweed as food has now also extended to North America, South America and Europe (McHugh 2003). The different species consumed present a great nutritional value as source of proteins, carbohydrates, minerals and vitamins. These seaweeds are harvested and utilized for a variety of purposes such as feed, fertilizer and as a source of raw material for industrial production of photochemical of commercial importance (Kirkman and Kendrick 1997; Robledo and Freile-Pelegrin 1997). The seaweeds are also known to contain bioactive products that display antibacterial, antiviral and antifungal properties (Trono 1999). Generally seaweeds at the surf zone also provide a niche environment for juvenile fishes and wrack-inhabiting organisms (Lenanton et al 1982). Accumulations of beach cast wreck are of immense ecological

Keywords. Catenella repens; biochemical composition; physico-chemical parameters; seasonal variation; data analysis. 
significance and contribute enormous quantities of organic matter in the ecosystem (Mitchell and Hunter 1970; Dooley 1972; Lenanton et al 1982; Robertson and Lenanton 1984; Safran and Omori 1990; Blanche 1992; Kirkman and Kendrick 1997), which provide nourishment to the macroalgae. Ecological significance and knowledge of chemical composition of marine seaweed is important for both assessment of nutritional value to marine invertebrate or vertebrate herbivores (Hawkins and Hartnoll 1983) and for the evaluation of potential sources of protein, carbohydrate and lipid for commercial use (Chapman and Chapman 1980) or for possible human consumption (Abbott 1988).

Seaweeds are exposed to seasonal variations of abiotic factors that influence their metabolic responses (photosynthesis and growth rates) and levels of proximate constituents (Orduña-Rojas et al 2002). For subtropical species seawater temperature, light and nutrients have been shown to be the primary factors that modify the seasonal photosynthesis in Hypnea musciformis (Wulfen) Lamouroux (Durako and Dawes 1980a) and Gracilaria tikvahiae McLachlan (Lapointe and Ryther 1978; Penniman and Mathieson 1985; Lapointe 1987). Seasonal variations in the chemical composition and nutritive value have been reported in common marine seaweeds from different parts of the world; Kaehler and Kennish (1996) reported the same from Hong Kong, Kumar (1993) from coastal India and Mercer et al (1993) from Ireland. The nutritional properties of seaweeds and their seasonal oscillation are poorly known and normally are evaluated from the chemical composition (Mabeau and Fleurence 1993).

In this context study on the temporal variations in chemical composition of tropical seaweeds from the Gangetic delta of Sundarbans, West Bengal, India is in a very dormant stage. This mangrove dominated deltaic lobe at the apex of Bay of Bengal exhibits significant spatial and temporal variations of salinity owing to varied geographic features. Recent studies suggest that, mariculture of this species would require subtropical to tropical condition and hence, this species can be considered as an important candidate for aquaculture due to the characteristics of its high carotenoid content (Mitra et al 2006). The common dominant seaweed under class rhodophyceae found in this region is Catenella repens.

The present paper aims to analyze the seasonal variations of the levels of proximate constituents (protein, carbohydrate, lipid and astaxanthin) with respect to relevant hydrological parameters (like surface water temperature, $\mathrm{pH}$, salinity, dissolved oxygen (DO), extinction coefficient ' $\mathrm{K}$ ', nutrients [nitrate $\left(\mathrm{NO}_{3}\right)$, phosphate $\left(\mathrm{PO}_{4}\right)$, silicate $\left(\mathrm{SiO}_{3}\right)$ ], phytopigment ( $\mathrm{Chl} a, b$ and $c$ ), etc.

\section{Materials and methods}

\subsection{Study site}

The Indian Sundarbans (within the latitude $21^{\circ} 13^{\prime} \mathrm{N}$ to $22^{\circ} 40^{\prime} \mathrm{N}$ and longitude $88^{\circ} 03^{\prime} \mathrm{E}$ to $89^{\circ} 07^{\prime} \mathrm{E}$ ) at the apex of the Gangetic delta is one of the most biologically productive and taxonomically diversified, low line, mangrove detritus based, open, dynamic, heterogeneous coastal ecotone. This mangrove forest has been declared as the World Heritage Site by IUCN in 1987, Biosphere Reserve under Man and Biosphere Programme by UNESCO in 1989 and is a proposed RAMSAR site. It is the only mangrove forest in the world that is inhabited by Royal Bengal Tiger (Panthera tigris tigris).

The climate of the area is humid (upto 96\%), tropical with temperature ranging from $11.8^{\circ} \mathrm{C}$ to $34.5^{\circ} \mathrm{C}$. The climate is monsoonal with an average rainfall of $1900 \mathrm{~mm}$ during monsoon months (July-October). The estuarine system becomes dominated by fresh water during monsoon resulting in strong predominance of ebb tides. From November-February, the system becomes salinity gradient dominated and during pre-monsoon period (March-June) effects of tide are considerably accentuated resulting in the system more or less marine dominated.

The low-lying tidal flats of Indian Sundarbans during the quaternary period have been developed from alluvial deposits of river Hugli, Saptamukhi and Matla together with tidal incursions. The soil consists of clayey loam or different black clay and there is no rock. The areas are about $1 \mathrm{~m}$ above the mean sea level and are submerged under saline estuarine waters for several hours in the spring tide twice a day.

Three stations selected in the eastern part of Indian Sundarbans region (figure 1) are distributed in three distinct salinity regimes: Gosaba - stn.1 $\left(22^{\circ} 08^{\prime} 53.66^{\prime \prime} \mathrm{N} ; 88^{\circ} 56^{\prime} 34.20^{\prime \prime} \mathrm{E}\right)$, Chhotomollakhali - stn. $2\left(22^{\circ} 10^{\prime} 21.74^{\prime \prime} \mathrm{N} ; 88^{\circ} 53^{\prime} 55.18^{\prime \prime} \mathrm{E}\right)$ and Bali stn. $3\left(22^{\circ} 04^{\prime} 35.17^{\prime \prime} \mathrm{N} ; 88^{\circ} 44^{\prime} 55.70^{\prime \prime} \mathrm{E}\right)$. The stations were selected on the basis of the availability of the red seaweed Catenella repens through seasons.

\subsection{Sampling and analysis of Catenella repens}

Seasonwise sampling was done from the uppermost littoral zone from November 2007 to October 2008 within $500 \mathrm{~m}$ coastal stretch at three different selected stations. During sampling, the shore washed seaweeds were collected by placing 5 random quadrates of $0.25 \mathrm{~m}^{2}$. The seaweeds thus harvested were brought to laboratory, washed and weighed. For determining biomass, the collected sample from each quadrate was weighed 


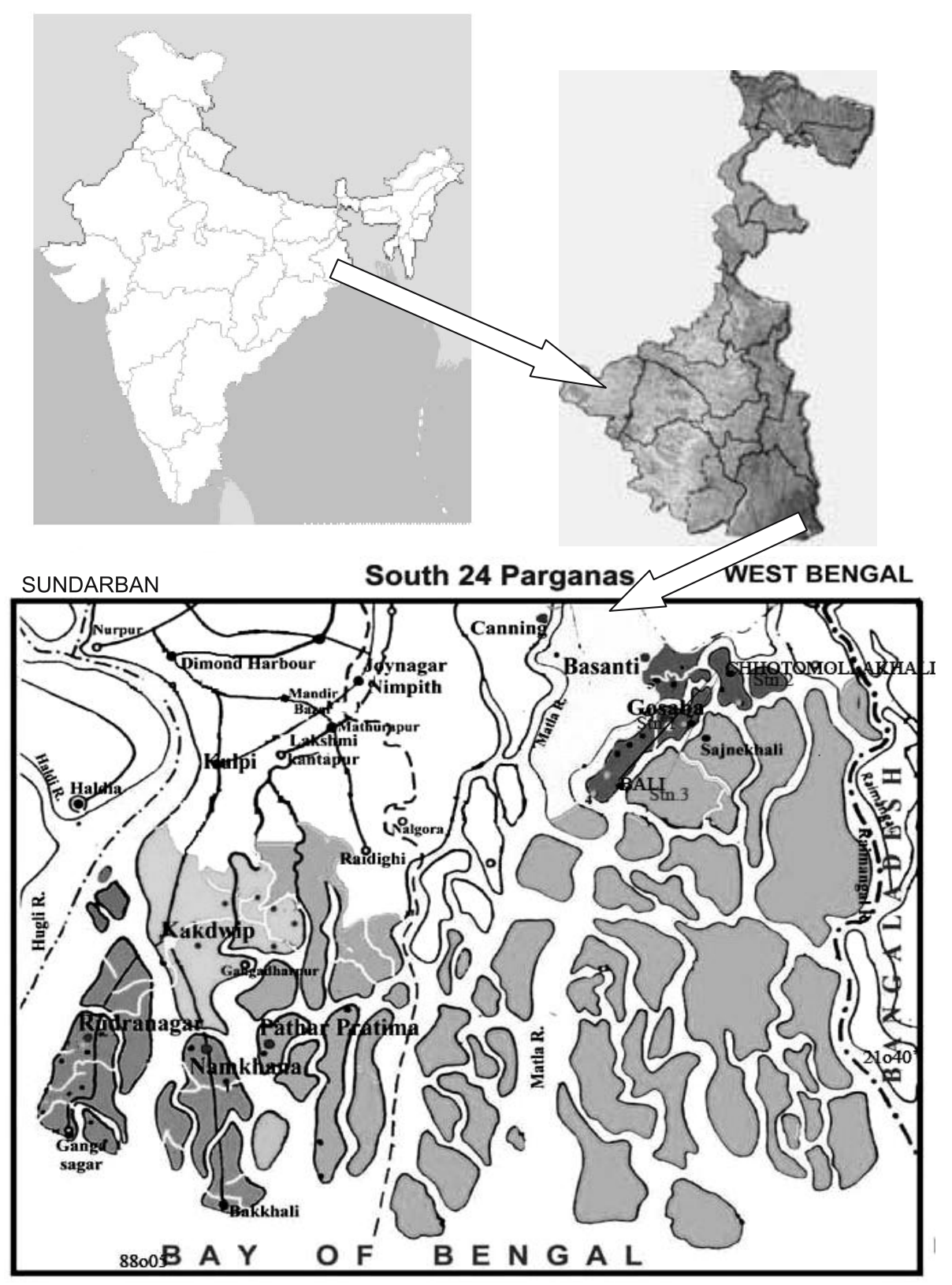

Figure 1. Map of India and West Bengal showing the study site of Indian Sundarbans.

and expressed as $\mathrm{g}$ fresh weight $\mathrm{m}^{-2}$. The data of biomass of red seaweed for the entire study period are shown in figure 2 .

Duplicate analyses were averaged for each of the triplicate samples for soluble carbohydrate, total protein, total lipid and astaxanthin. The total carbohydrate content was assayed by the phenolsulphuric acid method (Dubois et al 1956) after extraction with $2.5 \mathrm{~N} \mathrm{HCl}$. The results were calculated from a glucose standard curve. Total lipid was determined by Soxhlet method as described by Folch et al (1957). The total protein content was determined with Folin reagent with bovine albumin serving as standard (Lowry et al 1951). Astaxanthin was monitored by standard spectrophotometric method (Schuep and Schierle 1995). Its value in percentage was converted to ppm level for easy interpretation of data. Lipid, protein and carbohydrate contents were expressed as the percentage of dry weight. The results are given as a mean with standard deviation $( \pm \mathrm{SD})$ as quality assurance to the data.

\subsection{Analysis of hydrological parameters}

Surface water samples from all the selected stations were collected during high tide condition in clean TARSON bottles for analysis of hydrological parameters like surface water temperature, salinity, $\mathrm{pH}$, dissolved oxygen (DO), extinction coefficient 


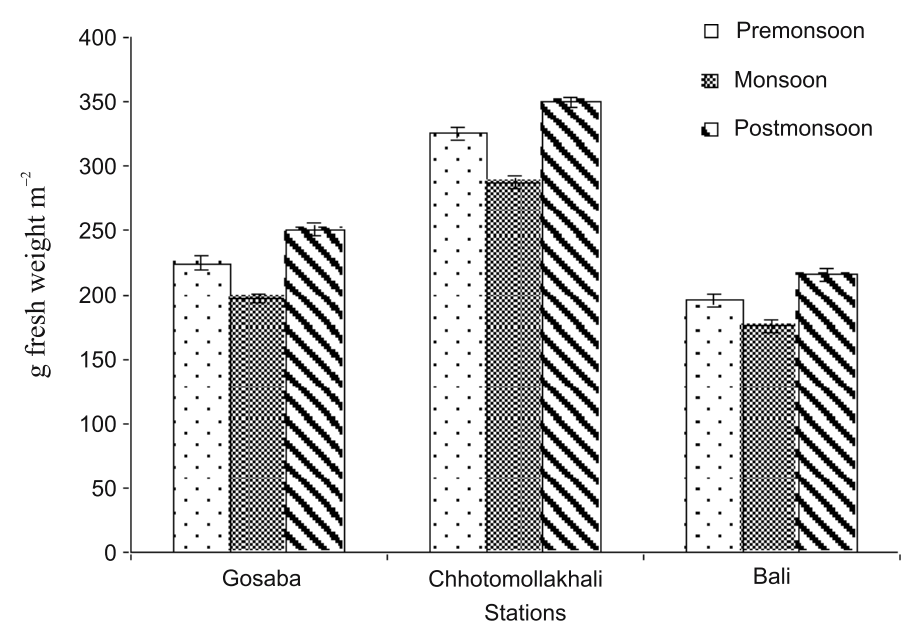

Figure 2. Variation in biomass content $\left(\mathrm{g}\right.$ fresh weight $\left.\mathrm{m}^{-2}\right)$ at three collection sites from Indian Sundarbans.

$(\mathrm{K})$, nitrate $\left(\mathrm{NO}_{3}\right)$, phosphate $\left(\mathrm{PO}_{4}\right)$ and silicate $\left(\mathrm{SiO}_{3}\right)$ on monthly basis. Analyses were done as per the standard methodology outlined in Strickland and Parsons (1972) and APHA (1998). The extinction co-efficient $(K)$, which is the inverse of transparency was determined as per the expression $K=1.44 / D$, where $D$ is the maximum depth of secchi disk visibility in meter (Raymont 1980). For pigment analysis, one litre of surface water was collected from each of the sampling stations for determination of the chlorophyll pigment ( $\mathrm{Chl} a, b$ and $c$ ) by spectrophotometric method after extraction with $90 \%$ acetone (Jeffrey and Humphrey 1975).

\subsection{Statistical analysis}

All data were expressed in terms of mean \pm SD (standard deviation) and range. In addition, data concerning the environmental parameters, biomass and content of proteins, carbohydrates, lipids and astaxanthin for the species were analyzed by Duncan's multiple range test at $p<0.05$ (SPSS 9.0 1999) for the identification of significant statistical seasonal differences during the study period. The Pearson correlation coefficient $(r)$ was also computed between the biochemical composition of the species and environmental parameters.

\section{Results and discussions}

\subsection{Spatial and temporal variation in observed variables}

Data on environmental parameters and biomass of C. repens are reported in table 1 and figure 2 . During the study period water temperature varied from $28.20 \pm 0.05^{\circ} \mathrm{C}$ during post-monsoon (stn.1) to $32.65 \pm 0.05^{\circ} \mathrm{C}$ during pre-monsoon (stn.3). Salinity oscillated between $11.48 \pm 0.03 \%$ at stn.1 (monsoon) to $24.33 \pm 0.15 \%$ at stn.3 (pre-monsoon). Similar trend of $\mathrm{pH}$ was also noted throughout the study period with low values during monsoon $(8.08 \pm 0.01)$ at stn. 1 and high values during pre-monsoon $(8.31 \pm 0.02)$ at stn.3. Extinction coefficient which is a measure of turbidity in water showed highest values during monsoon $\left(9.31 \pm 0.04 \mathrm{~m}^{-1}\right)$ at stn.1 and low values during pre-monsoon $\left(7.56 \pm 0.02 \mathrm{~m}^{-1}\right)$ at stn.3. Nutrient load $\left(\mathrm{NO}_{3}, \mathrm{PO}_{4}\right.$ and $\left.\mathrm{SiO}_{3}\right)$ showed higher values during monsoon and lower values during pre-monsoon excepting at stn.2, where $\mathrm{SiO}_{3}$ values were low during post-monsoon. This might be attributed to the heavy runoff and precipitation during monsoon which brings lot of nutrients from the adjacent landmasses, agricultural field and shrimp farms. The lower values of nutrients is due to the fact that $\mathrm{NO}_{3}, \mathrm{PO}_{4}$ and $\mathrm{SiO}_{3}$ (being the major building blocks of phytoplankton) are being absorbed from the ambient aquatic phase. Dissolved oxygen values were usually higher during monsoon $(6.21 \pm 0.03 \mathrm{mg} / \mathrm{l}$ at $\mathrm{stn} .1 ; 6.03 \pm 0.09 \mathrm{mg} / \mathrm{l}$ at $\mathrm{stn} .2$ and $5.52 \pm 0.19 \mathrm{mg} / \mathrm{l}$ at $\mathrm{stn} .3)$ in all the stations due to the heavy flushing from the rivers and churning actions of the seabed due to runoff processes. Phytopigment ( $\mathrm{Chl} a, b$ and $c$ ) showed highest values during pre-monsoon at stn. $3\left(4.10 \pm 0.02 \mathrm{mg} / \mathrm{m}^{3} ; 1.84 \pm 0.03 \mathrm{mg} / \mathrm{m}^{3}\right.$ and $2.06 \pm 0.03 \mathrm{mg} / \mathrm{m}^{3}$ respectively) and lowest values during monsoon at stn.1 $\left(2.39 \pm 0.05 \mathrm{mg} / \mathrm{m}^{3}\right.$; $0.91 \pm 0.04 \mathrm{mg} / \mathrm{m}^{3}$ and $1.77 \pm 0.02 \mathrm{mg} / \mathrm{m}^{3}$ respectively). The physico-chemical variables except surface water temperature and $\mathrm{pH}$ showed a sharp seasonal variation in all three selected stations (table 1). The surface water salinity, $\mathrm{pH}$, transparency (expressed as extinction coefficient) and 


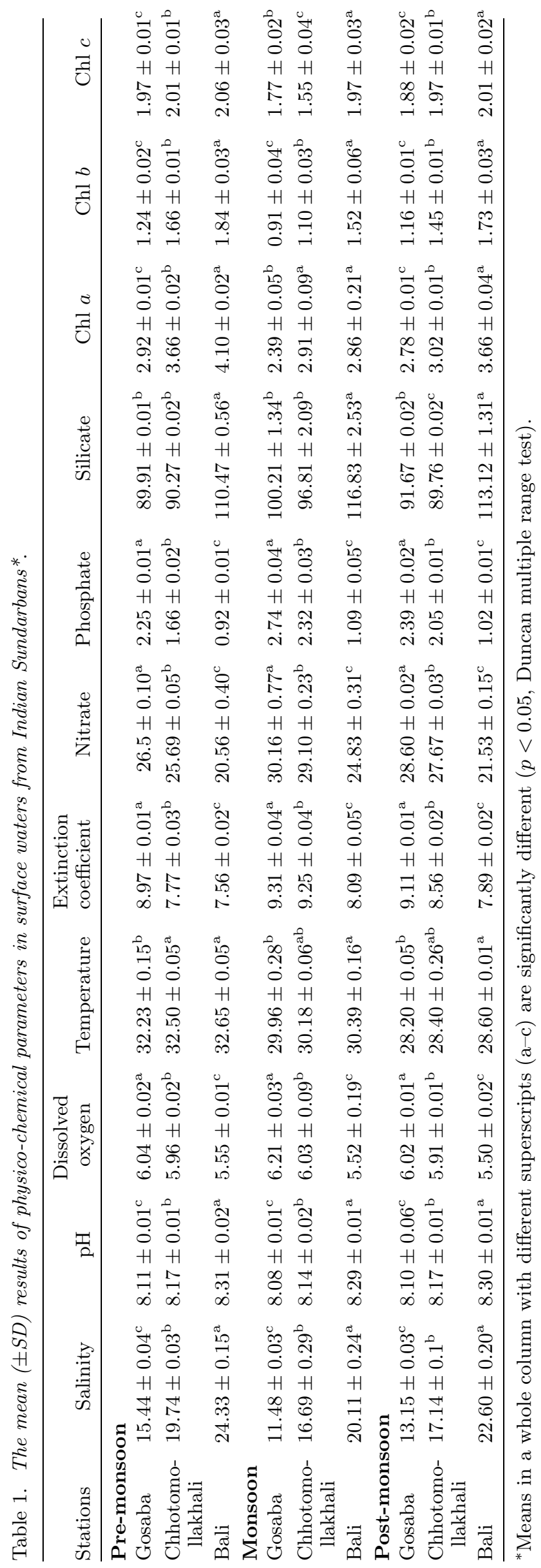

phytopigment (excepting Chl $c$ at stn.2) in the area of investigation varied as per the order station $3>$ station $2>$ station 1 . However, for nutrients (except silicate) and dissolved oxygen the order of variation was station $1>$ station $2>$ station 3 . This spatial trend was observed in all the seasons of the year, irrespective of stations.

Significant seasonal variations in biomass of Catenella repens have been observed in all the three sampling stations. The biomass showed a declining trend from post-monsoon to monsoon (figure 2). The biomass of seaweeds largely depends upon season, population structure and several other ecological factors (Krishnamurthy 1967). Further, the physico-chemical variable especially nutrients and salinity also contribute to the multiplication of the thallus (growth of seaweed) (Thakur et al 2008). The biomass of seaweed can be correlated with the abiotic factors that prevailed before or during the collection period (McQuaid 1985). In the present work, maximum growth of the red seaweed was observed during post-monsoon season; the period characterized by optimum nutrient load, temperature, salinity, $\mathrm{pH}$ and extinction coefficient. This is confirmed from the significant positive correlation between biomass and $\mathrm{pH}$ and significant negative correlation with nutrients $\left(\mathrm{NO}_{3}\right.$ and $\left.\mathrm{PO}_{4}\right)$ and extinction coefficient excepting phytopigment, surface water temperature and salinity (table 3 ). Seaweeds as compared to other marine plants are shortlived with successive growth periods and more than two growth peaks during their lifespan when the season is conducive (Thakur et al 2008). The lowest biomass values obtained during monsoon could be attributed to an intermittent period in which some population rejuvenate and recover from wholesome detachment. Ambient parameter is also not favourable during monsoon because of high turbidity that prevents light penetration for photosynthetic activities of seaweeds. The seaweed growth season in Indian Sundarbans begins from November to March. In general, biomass maximum coincides with carbohydrate maximum suggesting a link between seaweed growth and carbohydrate content (Marinho-Soriano et al 2006). However, our result did not support the above fact because of extremely high surface water temperature and salinity during pre-monsoon; which is a characteristic feature of the present geographical locale. This condition results in desiccation and subsequent reduction of seaweed biomass.

Protein values showed more or less similar trend in all the three stations and the values were in order station $1>$ station $2>$ station 3 . The fluctuation in the protein values in all the three stations can be explained by variation in environmental conditions such as temperature, salinity and nutrients. 
Table 2. The mean ( $\pm S D$ ) values of protein, lipid, carbohydrate and astaxanthin in Catenella repens from Indian Sundarbans*.

\begin{tabular}{|c|c|c|c|c|}
\hline Stations & $\begin{array}{c}\text { Protein } \\
\text { (\% of dry weight) }\end{array}$ & $\begin{array}{c}\text { Lipid } \\
\text { (\% of dry weight) }\end{array}$ & $\begin{array}{l}\text { Carbohydrate } \\
\text { (\% of dry weight) }\end{array}$ & $\begin{array}{c}\text { Astaxanthin } \\
\text { (ppm of dry weight) }\end{array}$ \\
\hline \multicolumn{5}{|l|}{ Pre-monsoon } \\
\hline Gosaba & $9.51 \pm 0.73^{\mathrm{a}}$ & $0.19 \pm 0.02^{\mathrm{a}}$ & $25.42 \pm 1.18^{\mathrm{c}}$ & $104.08 \pm 2.72^{\mathrm{c}}$ \\
\hline Chhotomollakhali & $8.66 \pm 0.78^{\mathrm{a}}$ & $0.18 \pm 0.02^{\mathrm{a}}$ & $28.48 \pm 1.45^{\mathrm{b}}$ & $134.41 \pm 3.12^{\mathrm{b}}$ \\
\hline Bali & $2.78 \pm 0.30^{\mathrm{b}}$ & $0.17 \pm 0.02^{\mathrm{a}}$ & $35.74 \pm 1.55^{\mathrm{a}}$ & $188.34 \pm 2.89^{\mathrm{a}}$ \\
\hline \multicolumn{5}{|l|}{ Monsoon } \\
\hline Gosaba & $16.03 \pm 0.96^{\mathrm{a}}$ & $0.23 \pm 0.02^{\mathrm{a}}$ & $23.09 \pm 1.41^{\mathrm{c}}$ & $87.49 \pm 2.34^{\mathrm{c}}$ \\
\hline Chhotomollakhali & $13.79 \pm 0.86^{\mathrm{b}}$ & $0.24 \pm 0.01^{\mathrm{a}}$ & $26.36 \pm 1.27^{\mathrm{b}}$ & $108.72 \pm 2.45^{\mathrm{b}}$ \\
\hline Bali & $8.53 \pm 1.14^{\mathrm{c}}$ & $0.22 \pm 0.02^{\mathrm{a}}$ & $28.93 \pm 0.18^{\mathrm{a}}$ & $174.45 \pm 3.62^{\mathrm{a}}$ \\
\hline \multicolumn{5}{|l|}{ Post-monsoon } \\
\hline Gosaba & $12.42 \pm 1.12^{\mathrm{a}}$ & $0.22 \pm 0.01^{\mathrm{a}}$ & $21.52 \pm 1.87^{\mathrm{b}}$ & $97.50 \pm 1.84^{\mathrm{c}}$ \\
\hline Chhotomollakhali & $11.43 \pm 1.86^{\mathrm{a}}$ & $0.20 \pm 0.01^{\mathrm{a}}$ & $23.32 \pm 1.67^{\mathrm{b}}$ & $128.07 \pm 2.72^{\mathrm{b}}$ \\
\hline Bali & $4.01 \pm 1.28^{\mathrm{b}}$ & $0.20 \pm 0.01^{\mathrm{a}}$ & $26.53 \pm 1.89^{\mathrm{a}}$ & $182.04 \pm 3.07^{\mathrm{a}}$ \\
\hline
\end{tabular}

${ }^{*}$ Means in a whole column with different superscripts $(\mathrm{a}-\mathrm{c})$ are significantly different $(p<0.05$, Duncan multiple range test).

This observation is confirmed by the positive correlation of protein content with dissolved nitrate and negative correlation with temperature and salinity (table 3). Carbohydrate values showed a reverse trend with respect to protein values in all the three selected stations. The values were in the order pre-monsoon $>$ monsoon $>$ post-monsoon, which emphasizes the role of temperature and salinity on carbohydrate synthesis. No significant temporal and spatial variations were observed for lipid content in the seaweed species thriving in the present study area (table 2). Astaxanthin values varied both spatially and temporally as per the order station $3>$ station $2>$ station 1 and pre-monsoon $>$ post-monsoon $>$ monsoon respectively. This might be probably due to the proximity of these stations to Bay of Bengal and higher temperature prevailing during pre-monsoon in the study site. This has been supported by several workers that environmental variables such as high irradiance, nutrient deficiency, high salinity and high temperature play a leading role in astaxanthin accumulation (Kobayashi et al 1992; Tjahjono et al 1994; Harker et al 1996; Boussiba 2000; Sarada et al 2002).

\subsection{Seasonal variation in biochemical composition}

The protein content showed highly significant seasonal variation $(p<0.05)$ with higher values during monsoon $(16.03 \pm 0.96 \%$ of dry weight at stn.1) owing to the presence of high nitrate load in the ambient waters (table 2). Similar results were observed by Bird (1984) while working with Gracilaria verrucosa. The dependence of protein level in algae on available nitrogen was also pointed out by Lapointe (1981) and Dawes (1998).
Significant seasonal variations in carbohydrate content of the seaweed was also observed in the present study $(p<0.05)$, irrespective of stations (table 2). The values were highest in premonsoon and lowest in post-monsoon indicating the role of surface water temperature to be vital for photosynthesis. The positive influence of water temperature, salinity and $\mathrm{pH}$ on carbohydrate synthesis was confirmed by several workers (Munda and Kremer 1977; Perfeto 1998). Significant positive correlation between salinity and surface water temperature and carbohydrate values in our study also supports the above results (table 3 ). The inverse relationship between carbohydrate and protein with temperature and salinity correspond to a pattern observed for several species of seaweeds (Mourandi-Givernaud et al 1993). The trend may be attributed to the positive role of light intensity, temperature and decrease of nitrogen for carbohydrate synthesis, while for the proteins these parameters act inversely (Rosemberg and Ramus 1982; Rotem et al 1986). Thus, the active period of carbohydrate synthesis coincides with the decrease in protein concentration in seaweed and vice-versa.

In general, seaweeds exhibit low lipid contents (Dawes 1998). The lipid content ranged from $0.17 \pm 0.02 \%$ of dry weight at stn.3 (pre-monsoon) to $0.24 \pm 0.01 \%$ of dry weight at stn.2 (monsoon). These values were smaller than those obtained for most seaweed, which range from $1 \%$ to $3 \%$ of dry matter as reported by Mabeau and Fleurence (1993). Although this value is relatively low, it is comparable to the results obtained previously by Indergaard and Minsaas (1991).

Astaxanthin is widely used as a natural red colourant in marine fish aquaculture (Johnson 1991; Benemann 1992). The coincidence of high 
Table 3. Correlation coefficients between environmental variables and biochemical composition of Catenella repens at three collection sites from Indian Sundarbans.

\begin{tabular}{|c|c|c|c|c|c|}
\hline & Biomass & Protein & Carbohydrate & Lipid & Astaxanthin \\
\hline \multicolumn{6}{|l|}{ Gosaba } \\
\hline Salinity & 0.147 & $-0.950^{*}$ & $0.490^{* *}$ & $-0.775^{*}$ & $0.944^{*}$ \\
\hline $\mathrm{pH}$ & $0.728^{*}$ & $-0.754^{*}$ & 0.161 & -0.393 & $0.777^{*}$ \\
\hline Dissolved Oxygen & $-0.881^{*}$ & $0.794^{*}$ & 0.058 & $0.540^{* *}$ & $-0.860^{*}$ \\
\hline Temperature & $-0.465^{* *}$ & $-0.464^{* *}$ & $0.798^{*}$ & $-0.498^{* *}$ & 0.428 \\
\hline Extinction coefficient & $-0.603^{*}$ & $0.940^{*}$ & -0.340 & $0.760^{*}$ & $-0.940^{*}$ \\
\hline Nitrate & $-0.484^{* *}$ & $0.908^{*}$ & -0.437 & $0.796^{*}$ & $-0.891^{*}$ \\
\hline Phosphate & $-0.695^{*}$ & $0.933^{*}$ & -0.270 & $0.740^{*}$ & $-0.947^{*}$ \\
\hline Silicate & $0.760^{*}$ & $0.915^{*}$ & -0.217 & $0.656^{*}$ & $-0.938^{*}$ \\
\hline Chl $a$ & $0.696^{*}$ & $-0.930^{*}$ & 0.257 & $-0.683^{*}$ & $0.961^{*}$ \\
\hline Chl $b$ & $0.698^{*}$ & $-0.934^{*}$ & 0.283 & $-0.721^{*}$ & $0.950^{*}$ \\
\hline Chl $c$ & $0.518^{* *}$ & $-0.882^{*}$ & 0.432 & $-0.822^{*}$ & $0.836^{*}$ \\
\hline Biomass & & $-0.504^{* *}$ & -0.394 & -0.309 & $0.557^{*}$ \\
\hline Protein & & & -0.440 & $0.805^{*}$ & $-0.883^{*}$ \\
\hline Carbohydrate & & & & $-0.484^{* *}$ & 0.262 \\
\hline Lipid & & & & & $-0.735^{*}$ \\
\hline \multicolumn{6}{|l|}{ Chhotomollakhali } \\
\hline Salinity & 0.226 & $-0.860^{*}$ & $0.597^{*}$ & $-0.777^{*}$ & $0.770^{*}$ \\
\hline $\mathrm{pH}$ & $0.739^{*}$ & $-0.596^{*}$ & 0.149 & $-0.603^{*}$ & $0.719^{*}$ \\
\hline Dissolved Oxygen & $-0.966^{*}$ & 0.319 & 0.392 & $0.445^{* *}$ & $-0.566^{*}$ \\
\hline Temperature & -0.309 & $-0.497^{* *}$ & $0.830^{*}$ & -0.343 & 0.297 \\
\hline Extinction coefficient & $-0.586^{*}$ & $0.889^{*}$ & -0.347 & $0.886^{*}$ & $-0.938^{*}$ \\
\hline Nitrate & $-0.549^{* *}$ & $0.885^{*}$ & -0.371 & $0.871^{*}$ & $-0.918^{*}$ \\
\hline Phosphate & $-0.519^{* *}$ & $0.900^{*}$ & -0.366 & $0.892^{*}$ & $-0.912^{*}$ \\
\hline Silicate & $-0.871^{*}$ & $0.736^{*}$ & 0.230 & $0.843^{*}$ & $-0.876^{*}$ \\
\hline Chl $a$ & 0.214 & $-0.867^{*}$ & $0.594^{*}$ & $-0.779^{*}$ & $0.763^{*}$ \\
\hline Chl $b$ & $0.700^{*}$ & $-0.924^{*}$ & 0.207 & $-0.924^{*}$ & $0.960^{*}$ \\
\hline $\mathrm{Chl} c$ & $0.883^{*}$ & $-0.892^{*}$ & 0.044 & $-0.892^{*}$ & $0.971^{*}$ \\
\hline Biomass & & $-0.631^{*}$ & -0.374 & $-0.631^{*}$ & $0.803^{*}$ \\
\hline Protein & & & -0.243 & $0.887^{*}$ & $-0.741^{*}$ \\
\hline Carbohydrate & & & & 0.022 & 0.098 \\
\hline Lipid & & & & & $-0.897^{*}$ \\
\hline \multicolumn{6}{|l|}{ Bali } \\
\hline Salinity & $0.654^{*}$ & $-0.920^{*}$ & $0.861^{*}$ & $-0.812^{*}$ & $0.884^{*}$ \\
\hline $\mathrm{pH}$ & 0.188 & $-0.680^{*}$ & 0.418 & $-0.913^{*}$ & $0.602^{*}$ \\
\hline Dissolved Oxygen & -0.102 & 0.073 & -0.122 & 0.022 & -0.147 \\
\hline Temperature & -0.362 & -0.230 & $0.657^{*}$ & $-0.587^{*}$ & $0.450^{* *}$ \\
\hline Extinction coefficient & -0.449 & $0.851^{*}$ & $-0.933^{*}$ & $0.877^{*}$ & $-0.901^{*}$ \\
\hline Nitrate & $-0.744^{*}$ & $0.944^{*}$ & $-0.778^{*}$ & $0.781^{*}$ & $-0.867^{*}$ \\
\hline Phosphate & $-0.476^{* *}$ & $0.787^{*}$ & $-0.937^{*}$ & $0.831^{*}$ & $-0.925^{*}$ \\
\hline Silicate & $-0.523^{* *}$ & $0.865^{*}$ & $-0.653^{*}$ & $0.746^{*}$ & $-0.720^{*}$ \\
\hline Chl $a$ & $0.665^{*}$ & $-0.928^{*}$ & $0.785^{*}$ & $-0.793^{*}$ & $0.836^{*}$ \\
\hline Chl $b$ & $0.664^{*}$ & $-0.888^{*}$ & $0.822^{*}$ & $-0.750^{*}$ & $0.851^{*}$ \\
\hline $\mathrm{Chl} c$ & $0.465^{* *}$ & $-0.766^{*}$ & $0.850^{*}$ & $-0.855^{*}$ & $0.909^{*}$ \\
\hline $\begin{array}{l}\text { Biomass } \\
\text { Protein }\end{array}$ & & $-0.670^{*}$ & $\begin{array}{c}0.417 \\
-0.686^{*}\end{array}$ & $\begin{array}{r}-0.250 \\
0.811^{*}\end{array}$ & $\begin{array}{r}0.580^{*} \\
-0.746^{*}\end{array}$ \\
\hline $\begin{array}{l}\text { Carbohydrate } \\
\text { Lipid }\end{array}$ & & & & $-0.681^{*}$ & $\begin{array}{r}0.891^{*} \\
-0.743^{*}\end{array}$ \\
\hline
\end{tabular}

${ }^{*}$ Significance $(p<0.01) \quad{ }^{* *}$ Significance $(p<0.05)$. 
astaxanthin value of Catenella repens with its carbohydrate level in the pre-monsoon season (table 2) was observed in the present study. The correlation values, however, indicate significant positive correlation of seaweed astaxanthin with salinity (table 3), in all the stations, but with surface water temperature, such positive correlations were not observed for all the stations. This might be due to tropical type of climate in the present geographical locale, where temperature oscillates little with season. Similar results on increase in carotenoids content with increasing temperature and salinity with high astaxanthin production were also found by Tripathy et al (2002). In case of nutrient, Ausich (1997) stated that when the Haematococcus culture is subjected to stress in which nutrients are eliminated from growth medium then the alga produces and accumulate astaxanthin. In our case also significant negative correlation $(p<0.01)$ at all the selected stations depict that astaxanthin accumulation increases with decrease in nutrient level (table 3).

The results obtained in our study establish the fact that physico-chemical parameters have profound influence on the biochemical composition of red seaweed, Catenella repens. Significant correlation values computed among the environmental parameters and protein, lipid, carbohydrate, astaxanthin suggest that the abiotic parameters have potential role on biosynthetic pathways of seaweed. A number of studies are still needed to evaluate the nutritional potentiality of this seaweed for its mass cultivation as food source for the coastal communities.

\section{Acknowledgements}

This research was supported financially by Department of Science and Technology, WOS-B Scheme, Government of India and infrastructural facilities by Department of Marine Science and Department of Zoology, University of Calcutta.

\section{References}

Abbott I A 1988 Food and food products from algae; In: Algae and Human Affairs (eds) Lembi C A and Waaland J R (Cambridge: Cambridge University Press) pp. $135-147$.

APHA 1998 Standard Methods for the Examination of Water and Waste Water; 20th edn, American Public Health Association, USA.

Ausich R L 1997 Commercial opportunities for carotenoid production by biotechnology; Pure Appl. Chem. 69 2169-2173.

Benemann J R 1992 Microalgae aquaculture feeds; J. Appl. Phycol. 4 233-245.
Bird K T 1984 Seasonal variation in protein: carbohydrate ratios in a subtropical estuarine alga, Gracilaria verru$\cos a$, and the determination of nitrogen limitation status using these ratios; Bot. Mar. 27(3) 111-115.

Blanche K R 1992 Preliminary observations on the distribution and abundance of seaweed flies (Diptera: Coelopidae) on beaches in the Gosford district of New South Wales, Australia; Aus. J. Ecol. 17 27-34.

Boussiba S 2000 Carotenogenesis in the green algae Haematococcus pluvialis: Cellular physiology and stress response; Physiol. Plant. 108 111-117.

Chapman V J and Chapman D J 1980 Seaweeds and Their Uses (London: Chapman and Hall).

Dawes C J 1998 Marine Botany (New York: John Wiley and Sons, Inc.) pp. 480.

Dooley J K 1972 Fishes associated with the pelagic Sargassum complex, with a discussion of the Sargassum community; Contrib. Mar. Sci. 16 1-32.

Dubois M, Gilles K A, Hamilton J K, Rebers P A and Smith F 1956 Colorimetric methods for determination of sugars and related substances; Analit. Chem. 28 350-356.

Durako M J and Dawes C J 1980a A comparative seasonal study of two populations of Hypnea musciformis from the East and West Coasts of Florida, USA. II. Photosynthetic and respiratory rates; Mar. Biol. 59 157-162.

Folch J, Lees M and Solam-Stanley G H 1957 A simple method for the isolation and purification of claot lipid from animal tissue; J. Biol. Chem. 226 497-509.

Harker M, Tsavalos A J and Young A J 1996 Factors responsible for astaxanthin formation in the chlorophyte Haematococcus pluvialis; Bioresour. Technol. 55 207-214.

Hawkins S J and Hartnoll R G 1983 Grazing of intertidal algae by marine herbivores; Oceanogr. Mar. Biol. Ann. Rev. 21 195-282.

Indergaard M and Minsaas J 1991 Animal and Human Nutrition; In: Seaweed Resources in Europe. Uses and Potential (eds) Guiry G and Blunden G (New York: John Wiley and Sons) 21-64.

Jeffrey S W and Humphrey G F 1975 New spectrophotometric equations for determining chlorophylls $a, b, c 1$, and $c 2$ in higher plants, algae and natural phytoplankton; Biochem. Physiol. Pflanz. 167 191-194.

Johnson E A 1991 Astaxanthin from microbial sources; Crit. Rev. Biotechnol. 11 297-326.

Kaehler S and Kennish R 1996 Summer and winter comparisons in the nutritional value of marine macroalgae from Hong Kong; Bot. Mar. 39 11-17.

Kirkman H and Kendrick G A 1997 Ecological significance and commercial harvesting of drifting and beach cast macroalgae and seagrasses in Australia: A review; J. Appl. Phycol. 9 311-326.

Kobayashi M, Kakizono T, Nishio N and Nagai S 1992 Effects of light intensity, light quality and illumination cycle on astaxanthin formation in a green alga Haematococcus pluvialis; J. Ferment. Bioeng. 74 61-63.

Krishnamurthy V 1967 Seaweed drift on the Indian coast; Proceedings of the Symposium "Indian Ocean"; Bull. Nat. Inst. Sci. India 38 657-666.

Kumar V 1993 Biochemical constituents of marine algae from Tuticorin coast; Indian J. Mar. Sci. 22 138-140.

Lapointe B E 1981 The effects of light and nitrogen on growth, pigment content, and biochemical composition of Gracilaria foliifera v. angustissima (Gigartinales, Rhodophyta); J. Phycol. 17 90-95.

Lapointe B E 1987 Phosphorus- and nitrogen-limited photosynthesis and growth of Gracilaria tikvahiae (Rhodophyceae) in the Florida Keys: An experimental field study; Mar. Biol. 93 561-568. 
Lapointe B E and Ryther J H 1978 Some aspects of the growth and yield of Gracilaria tikvahiae in culture; Aquaculture 15 185-193.

Lenanton R C J, Robertson A I and Hansen J A 1982 Near shore accumulations of detached macrophytes as nursery areas for fish; Mar. Ecol. Prog. Series 9 51-57.

Lowry O H, Farr A L, Randall R J and Rosebrough N J 1951 Protein measurement with Folin phenol reagent; J. Biol. Chem. 193 265-275.

Mabeau S and Fleurence J 1993 Seaweed in food products: Biochemical and nutritional aspects; Trends Food Sci. Technol. 4 103-107.

Marinho-Soriano E, Fonseca P C, Carneiro M A A and Moreira W S C 2006 Seasonal variation in the chemical composition of two tropical seaweeds; Bioresour. Technol. 97 2402-2406.

McHugh D J 2003 A guide to the seaweed industry; FAO Fisheries Technical Paper no. 441. Rome, FAO, p. 105.

McQuaid C D 1985 Seasonal variation in biomass and zonation of nine intertidal algae in relation to changes in radiation, sea temperature and tidal regime; Bot. Mar. 28 $539-544$.

Mercer J P, Mai K S and Donlon J 1993 Comparative studies on the nutrition of two species of abalone, Haliotis tuberculata Linnaeus and Haliotis discus hannai Ino. I. Effects of algal diets on growth and biochemical composition; Invertebrate Reprod. Develop. 23 2-3.

Mitchell C T and Hunter J R 1970 Fishes associated with drifting kelp, Macrocystis pyrifera, off the coast of southern California and northern Baja California; Calif. Fish Game. 56 288-297.

Mitra A, Banerjee K and Banerjee A 2006 Screening mangroves in search of Astaxanthin; Seshaiyana. 14(1) $1-2$.

Mourandi-Givernaud A, Givernaud T, Morvan H and Cosson J 1993 Annual variations of the biochemical composition of Gelidium latifolium (greville) Thuret et Bornet; Hydrobiologia. 260/261 607-612.

Munda I M and Kremer B P 1977 Chemical composition and physiological properties of fucoids under conditions of reduced salinity; Mar. Biol. 42 9-15.

Orduña-Rojas J, Robledo D and Dawes C J 2002 Studies on the Tropical Agarophyte Gracilaria cornea J. Agardh (Rhodophyta, Gracilariales) from Yucatán, Mexico. I. Seasonal Physiological and Biochemical Responses; Bot. Mar. 45 453-458.

Penniman C A and Mathieson A C 1985 Photosynthesis of Gracilaria tikvahiae McLachlan (Gigartinales, Rhodophyta) from the Great Bay Estuary, New Hampshire; Bot. Mar. 28 427-435.

Perfeto P N M 1998 Relation between chemical composition of Grateloupia doryphora (Montagne) Howe,
Gymnogongrus griffithsiae (Turner) Martius, and abiotic parameters; Acta. Bot. Bras. 12 77-88.

Raymont J E G 1980 Plankton and productivity in the oceans, Vol. 1. Phytoplankton (New York: Pergamon Press) 489 pp.

Robertson A I and Lenanton R C J 1984 Fish community structure and food chain dynamics in the surf-zone of sandy beaches: The role of detached macrophyte detritus; J. Exp. Mar. Biol. Ecol. 84 265-283.

Robledo D and Freile-Pelegrin Y 1997 Chemical and mineral composition of six potentially edible seaweed species of Yucatan; Bot. Mar. 40 301-306.

Rosemberg G and Ramus J 1982. Ecological growth strategies in the seaweeds Gracilaria follifera (Rhodophyceae) and Ulva sp. (Chlorophyceae): Soluble nitrogen and reserve carbohydrates; Mar. Biol. 66 251-259.

Rotem A, Roth-Bejeranu N and Arad S M 1986 Effect of controlled environmental conditions on starch and agar contents of Gracilaria sp. (Rhodophyceae); J. Phycol. 22 $117-121$.

Safran P and Omori M 1990 Some ecological observations on fishes associated with drifting seaweed off Tohoku coast; Mar. Biol. 105 395-402.

Sarada R, Tripathi U and Ravishankar G A 2002 Influence of stress on astaxanthin production in Haematococcus pluvialis grown under different culture conditions; Proc. Biochem. 37 623-627.

Schuep W and Schierle J 1995 Astaxanthin determination of stabilized, added astaxanthin in fish feeds and premixes; In: Carotenoids isolation and analysis; Birkhauser Verbag Basel 1A pp. 273-276.

SPSS Inc. 1999 SPSS ${ }^{\mathrm{R}}$ Base 9.0 Application Guide. SPSS Inc., Chicago.

Strickland J D H and Parsons T R 1972 A practical handbook of seawater analysis. 2nd edn, Bull. Fish. Res. Bd Can. $1671-310$.

Thakur M C, Reddy C R K and Jha B 2008 Seasonal variation in biomass and species composition of seaweeds stranded along Port Okha, northwest coast of India; J. Earth Syst. Sci. 117 211-218.

Tjahjono A E, Hayama Y, Kakizono T, Terada Y, Nishio N and Nagai S 1994 Hyper-accumulation of astaxanthin in a green alga Haematococcus pluvialis at elevated temperatures; Biotechnol. Lett. 16 $133-138$.

Tripathy U, Sarada R and Ravishankar G A 2002 Effect of culture conditions on growth of green alga - Haematococcus pluvialis and astaxanthin production; Acta Physiol. Plant. 24(3) 323-329.

Trono Jr G C 1999 Diversity of the seaweed flora of the Philippines and its utilization; Hydrobiologia 398/399 $1-6$. 